i/lub reforma traktatowa sankcjonująca dzisiejsze reformy zacieśniające współpracę m.in. w gronie państw eurogrupy ${ }^{5}$.

Rekomendowana książka zawiera interesujący zbiór wielu punktów widzenia ukazujących UE jako jednego $\mathrm{z}$ wielu aktorów na arenie politycznych i gospodarczych stosunków międzynarodowych. Większością prezentowanych tez wpisuje się we wspólnotową narrację o UE. Autorzy mogą nie dostrzegać, że jednym $z$ efektów kryzysu jest powrót do propaństwowej narracji o Europie, w której wezwania do solidarności europejskiej nie zawsze są wystarczająco słyszalne. Nie zmienia to faktu, że wartością dodatnią książki jest jej interdyscyplinarność i dobrze dobrane instrumentarium badawcze oraz rzetelna analiza naukowa. Treść całej książi, jak i jej poszczególne rozdziały mogą posłużyć do przygotowania dobrej kwerendy na potrzeby pracy magisterskiej, lub też mogą stanowić materiał źródłowy na seminarium naukowe poświęcone przyszłości UE.

MIKOŁAJ J. TOMASZYK

\title{
Polityka zagraniczna. Aktorzy - potencjaly - strategie, red. Teresa Loś-Nowak, Wydawnictwo Poltext, Warszawa 2011, ss. 575.
}

Stephen M. Walt, badacz stosunków międzynarodowych uznawany za przedstawiciela szkoły neorealistycznej, w jednym ze swoich często cytowanych artykułó ${ }^{1}{ }^{1}$ zapytuje, dlaczego osoby odpowiedzialne za tworzenie podstaw polityki zagranicznej oraz jej praktycy powinni zwracać uwagę na studia poświęcone tej problematyce. Szukając odpowiedzi, zauważa on, że istnieje silna więź łącząca świat teorii i ontologii. Teoria to „okulary”, przez które patrzymy na otaczający nas świat. Pozwala ona politykom wyselekcjonować z „lawiny informacyjnej” najistotniejsze wiadomości, dzięki czemu mogą oni podejmować właściwe decyzje polityczne. Jednocześnie teoretycy, odpowiedzialni za koncepcyjne ukształtowanie podstaw polityki zagranicznej, nie są w stanie tego dokonać bez odpowiedniej znajomości szeregu procesów i zjawisk zachodzących w realnym, otaczającym ich świecie.

Zagadnienie przedstawienia teoretyeznych i ontologicznych podstaw polityki zagranicznej poszczególnych państw, przy uwzględnieniu dryfu w systemie międzynarodowym w kierunku podmiotów nieterytorialnych, podejmuje Teresa Łoś-Nowak w dziele Polityka zagraniczna. Aktorzy - potencjaty - strategie. Wraz z grupą badaczy wywodzących się z rozmaitych ośrodków akademickich, m.in. z Wrocławia, Warszawy, Torunia, Olsztyna, Lublina i Gdańska prezentuje ona śmiałą i oryginalną wizję odejścia od schematycznego opisywania systemu międzynarodowego wyznaczanego przez metafore „Westfalii” jako hipotezy genezy w nauce o stosunkach międzynarodowych ${ }^{2}$. Wychodząc poza „granice” wyznaczone państwowocentryczną wizją stosunków międzynarodowych, zauważa: ,... z teoretycznego punktu widzenia jest jasne, że polity-

5 Jest to również jedna z konkluzji spotkania Grupy Refleksji w Palmie na Majorce. Gospodarz spotkania min. J. M. G. Margallo przypomnial, że nadszedł czas na odnowę UE i ma nadzieję na lepszy efekt niż miało to miejsce w Maastricht czy w Rzymie. Nadszedł czas na powstanie rządu gospodarczego Europy, który będzie bronił i państw, i wspólnej waluty. UE zdaniem Margallo powinna dążyć do bezpośrednich wyborów przewodniczącego KE. EurActiv z dnia 23.07.2012 r.

S. M. Walt, International Relations: One World, Many Theories, „Foreign Policy”, No. 110, Special Edition: Frontiers of Knowledge (Spring, 1998), s. $29-46$.

2 A. Gałganek, ,, Westfalia” jako hipoteza genezy w nauce o stosunkach międzynarodowych, w: Późnowestfalski lad międzynarodowy, red. M. Pietraś, K. Marzęda, Lublin 2008, s. 23. 
ka zagraniczna wiąże się z państwem [...], w praktyce jednak nie do końca jest to tak oczywiste" (s. 13-14). Istnieje bowiem wiele przesłanek świadczących o wpływie korporacji transnarodowych i organizacji międzynarodowych na politykę zagraniczną państw. Wychodząc od tego założenia, T. Łoś-Nowak w dwóch rozdziałach otwierających książkę stopniowo buduje teoretyczne ramy rozważań poświęconych polityce poszczególnych państw i innych podmiotów wpływających na ich politykę zagraniczną. Zastanawiając się nad istotą polityki zagranicznej, ukazuje jej podstawowe nurty i modele polityczne (realizm, modernizm, postmodernizm). Rysuje przy tym podział na politykę zagraniczną jako funkcję przynależną państwu i politykę międzynarodową - obejmującą wszystkie formy aktywności podmiotów nieterytorialnych, w tym korporacji transnarodowych oraz Unii Europejskiej. Dostrzegając, że „obie polityki” są ważnym „fragmentem rzeczywistości międzynarodowej” (s. 29), dochodzi ona do wniosku, że w postwestfalskim, czy jak chce Marek Pietraś - ,późnowestfalskim "33 ładzie międzynarodowym, państwo przestało być kulą bilardową toczącą się po koleinach systemu międzynarodowego. Zostało bowiem, wpisane" w sieć powiązań międzynarodowych. Stąd zewnętrzna funkcja państw w coraz większym stopniu zaczyna przypominać politykę międzynarodową niż zagraniczną, w której zachowanie państw zależy w głównej mierze od „wewnętrznej struktury procesu decyzyjnego i struktury systemu międzynarodowego" (s. 45).

W części teoretycznej książki spójnie i przejrzyście prezentuje się, oprócz wspomnianych wyżej zagadnień, kwestię uczestnictwa w polityce międzynarodowej i zagranicznej, pozycję państwa w systemie międzynarodowym, potrzeby, interesy i cele państwa w polityce zagranicznej. Rozważania prowadzone są w głównej mierze na gruncie neorealizmu i neoliberalizmu. Szkoda jednak, że nie zdecydowano się rozszerzyć spojrzenia teoretycznego, wykorzystując dorobek konstruktywizmu, który stopniowo, od lat 80 . ubiegłego stulecia staje się coraz ważniejszym nurtem w nauce o stosunkach międzynarodowych.

Pozostałe częśsi pracy Autorzy poświęcili analizie polityki zagranicznej supermocarstw, mocarstw i mocarstw in statu nascendi (USA, Rosja, Chiny, Niemcy, Brazylia, Indie, Japonia, Unia Europejska, korporacje międzynarodowe), państw średniego rzędu (Polska, Ukraina, Turcja, Szwecja, Izrael, RPA) oraz państw małych i minipaństw (Czechy, Gruzja, Urugwaj, Senegal, Singapur, Liechtenstein, Surinam).

Najciekawszą wydaje się być część ukazująca politykę zagraniczną prowadzoną przez największe państwa. W tekście poświęconym USA, Justyna Zając umiejętnie ukazuje stopniową zmianę pozycji międzynarodowej Stanów Zjednoczonych, które zachowując prymat w wymiarze militarnym, w dziedzinie gospodarczej dzielą go $\mathrm{z}$ innymi podmiotami międzynarodowymi: Unią Europejską, Japonią i Chinami (s. 80). Te ostatnie, jak słusznie podkreśla Autorka, sąjeszcze dalekie od zastąpienia USA w roli hegemona światowego. Andrzej Czajkowski, wychodząc od dramatycznych zmian w stosunkach międzynarodowych, które nastąpiły wraz z końcem zimnej wojny, rysuje obraz Rosji, przedstawiając kolejne etapy jej polityki zagranicznej. Na uwagę zasługują rozważania Autora na temat rosyjskiego neoimperializmu. Zdaniem A. Czajkowskiego, ,neoimperializm można [...] rozpatrywać jako dążenie Rosji do dominacji na terenie postsowieckim, przy czym nie na całym” (s. 89). Słusznie zauważa on, że „Rosja w dającej się przewidzieć perspektywie nie jest w stanie odzyskać utraconej wielkości w znaczeniu tej z czasów radzieckich" (s. 103). W części dzieła dotyczącej mocarstw dużo miejsca poświęca się także tzw. rynkom wschodzącym (ang. emerging markets) na czele z Chinami, Indiami i Brazylią. Joanna Marszałek-Kawa w interesujący sposób prezentuje chińską drogę do supermocarstwowości, a Marcin Gawrycki wskazuje na Brazylię jako mocarstwo regionalne (s. 149). Analizie poddano także Indie jako mocarstwo, które uwikłane jest w konflikt z Pakistanem o Kaszmir, z Chinami w Zatoce Bengalskiej, a także z Bangladeszem i Nepalem, co sprawia, że subsystem

3 Późnowestfalski lad międzynarodowy, red. M. Pietraś, K. Marzęda, Lublin 2008. 
bezpieczeństwa Azji Południowej trudno uznać za stabilny. Na szczególną uwagę zasługują również dwa rozdziały poświęcone tzw. podmiotom nieterytorialnym jako mocarstwom. W oryginalnym ujęciu Ryszarda Zięby, polityka zagraniczna prowadzona przez Unię Europejską może być postrzegana przez pryzmat: ekonomii jako „wspólnotowa polityka zagraniczna” (s. 217), polityki jako „Wspólna Polityka Zagraniczna i Bezpieczeństwa” (s. 223) oraz w kontekście polityczno-militarnym jako „Wspólna Polityka Bezpieczeństwa i Obrony” (s. 229). W równie ciekawym tekście Katarzyna Marzęda-Młynarska zastanawia się nad znaczeniem korporacji międzynarodowych w polityce międzynarodowej, które określa mianem „nowego fenomenu”. Z poglądem tym można się zgodzić jedynie czéściowo bowiem, jak zauważa sama Autorka, „ich [korporacji międzynarodowych - M.R.] »debiut« w badaniach na gruncie stosunków międzynarodowych przypadł na lata 70 . XX wieku" (s. 236). Z kolei niewątpliwym atutem tej części pracy jest zaprezentowanie wielowymiarowego wpływu korporacji transnarodowych na politykę międzynarodową (s. 245-256).

W części III i IV niniejszego działa podjęto wysiłek zanalizowania polityki zagranicznej państw średniego rzędu oraz państw małych i minipaństw. Na szczególną uwagę zasługuje ukazanie Polski, również w kontekście polityki Partnerstwa Wschodniego, zawieszonego między prometeizmem a mesjanizmem (283-285), Turcji stojącej „W rozkroku” między Wschodem a Zachodem i Izraela. Szkoda jednak, że w tej grupie państw nie znalazł się Iran, państwo niewątpliwie znaczące, uznawane za przeciwwagę w regionie dla ambicji Izraela. W ostatnim rozdziale scharakteryzowano politykę zagraniczną państw małych i minipaństw. Skupienie się na państwach różnorodnych pod niemal każdym względem, jak: Czechy, Gruzja, Senegal czy Liechtenstein należy uznać za zabieg właściwy, pozwalający czytelnikowi na wyrobienie perspektywy porównawczej.

Dzieło pod redakcją T. Łoś-Nowak prezentuje się jako praca staranna. Została zaopatrzona we wprowadzenie, część merytoryczną składającą się z czterech części, podsumowanie, rozległą bibliografię oraz indeks ułatwiający pracę z tekstem. Warto też zaznaczyć, że poszczególne rozdziały kończą się podsumowaniami, co systematyzuje wiedzę i pozwala na dokonanie koniecznych uogólnień.

Należy też zauważyć, że dzieło Teresy Łoś-Nowak wyróżnia się występowaniem tzw. novum. Na nowatorski charakter książki wpływa nie tylko jej przemyślana struktura, ale także umiejętne połączenie teorii i ontologii oraz wyjście poza tradycyjne postrzeganie polityki zagranicznej możliwe dzięki podkreśleniu znaczenia polityki międzynarodowej. Doceniając walory prezentowanej książki, należy zauważyć, że stanowi ona kolejny etap budowy polskiej szkoły myślenia o stosunkach międzynarodowych. Dzięki uwzględnieniu szerokiego spektrum zagadnień można ją uznać za lekturę obowiązkową dla studentów, naukowców oraz praktyków zajmujących się lub zainteresowanych polityką zagraniczną.

MAREK REWIZORSKI

\section{Janusz Józef Węc, Traktat lizboński. Polityczne aspekty reformy ustrojowej Unii Europejskiej w latach 2007-2009, Księgarnia Aka- demicka, Kraków 2011.}

Integracja europejska, to bardzo złożony proces, trwający w formie jaką dziś znamy od pierwszych lat po II wojnie światowej. Począwszy od różnych powojennych planów i koncepcji integracyjnych tworzonych przez europejskie elity społeczne i polityczne, poprzez powstanie Wspólnot Europejskich aż po utworzenie Unii Europejskiej, proces ten nigdy nie był statyczny, a wręcz przeciwnie - ulegał ciagłym modyfikacjom i kierował się własną wewnętrzną dynamiką. 